\title{
KONTEN KREATIF BERBASIS STORI LINGKUNGAN UNTUK MEDIA IKLAN PRODUK BERBAHAN DASAR ECENG GONDOK SEBAGAI UPAYA PENYELAMATAN LINGKUNGAN DAN PEMBERDAYAAN MASYARAKAT
}

\author{
${ }^{1}$ Thohiriyah, ${ }^{2}$ Christianti Tri Hapsari, dan ${ }^{3}$ Rahayu Puji Haryanti \\ Fakultas Bahasa dan Seni, Universitas Negeri Semarang \\ ${ }^{1}$ thohiriyah@mail.unnes.ac.id, ${ }^{2}$ christianti@mail.unnes.ac.id, dan ${ }^{3}$ rahayu_ph@mail.unnes.ac.id
}

\begin{abstract}
Abstrak: Lebih dari tujuh puluh persen (70\%) populasi eceng gondok menutupi permukaan Danau Raw a yang berdampak buruk untuk sisi lingkungan dan ekonomi. Eceng gondok menurunkan populasi biota seperti ikan dan nilai pariwisata. Solusi nyata dibutuhkan untuk menghadapi permasalahan ini. Kelompok masyarakat pegiat usaha UMKM berbasis pemberdayaan masyarakat dan potensi sumber daya alam lokal, Bengok Craft, di Desa Kesongo, Kecamatan Tuntang, Kabupaten Semarang dalam hal ini telah mengambil peran untuk menjadi bagian dari solusi atas permasalahan tersebut yakni dengan memproduksi kerajinan eceng gondok mulai dari tas eceng gondok, buku, hingga sandal serta aksesoris lainnya. Banyaknya produksi kerajinan ini kemudian diproses lebih lanjut oleh UMKM Bengok Craft seperti proses finishing dan juga didistribusikan di pasar. Akan tetapi, permasalahan lain muncul yakni pemasaran produk. Produk kerajinan ec eng gondok dipasarkan di pasar lokal dengan memanfaatkan media pemasaran daring seperti media sosial dan juga website dengan memanfaatkan media gambar atau foto produk. Konten pada media pemasaran masih belum cukup persuasif dan menarik minat pasar global. Merespon permasalahan ini, tim pengabdi sebagai akademisi memberikan solusi berupa pelatihan penulisan konten kreatif berbasis stori untuk media iklan produk kerajinan Bengok Craft yang melibatkan pengelola UMKM Bengok Craft dan warga desa yang menjadi tim iklan. Hasil dari kegiatan ini adalah peserta pelatihan menghasilkan konten iklan untuk media daring.
\end{abstract}

Kata kunci: Eceng Gondok, UMKM, Iklan, Konten kreatif, Stori

\section{Pendahuluan}

Pemanfaatan konten kreatif berbasis stori untuk media periklanan diakui efektif untuk menyampaikan pesan dan juga media untuk mempromosikan sesuatu (Padgett \& Allen, 1997; Cholewa-Wójcik \& Kawecka, 2015). Dalam membeli sebuah produk, konsumen lebih sering membeli dengan alasan untuk keinginan bukan karena kebutuhan akan manfaat suatu produk. Ikatan emosi antara konsumen dan produsen dapat menjadi media yang kuat untuk menggaet minat konsumen terhadap suatu produk (Taylor, 1999). Dalam sebuah iklan narasi yang memaparkan plot cerita, memunculkan karakter, masalah dan penyelesaiannya yang terhubung antara fiksi dan kenyataan, lebih mampu menarik emosi konsumen untuk terikat, ingat, dan tertarik membeli sebuah produk. Dengan konten narasi, sebuah produk yang diiklankan juga akan mempunyai makna lebih di mata konsumen (Escalas, 2006). Iklan dengan cerita narasi yang menarik dan disukai oleh konsumen akan mampu menggaet setengah dari populasi konsumen untuk membeli dibanding dengan iklan yang hanya mendorong tindakan untuk membeli (West, 
2015). Untuk itu, penggunaan konten kreatif berbasis stori untuk media iklan produk, terutama untuk produk UMKM dirasa sangatlah penting untuk upaya peningkatan penjualan dan alternatif pemasaran.

Target tim pengabdian adalah di Desa Kesongo, Kecamatan Tuntang, Kabupaten Semarang. Ditinjau dari segi geografis dan demografis, Desa Kesongo, Kecamatan Tuntang, Kabupaten Semarang, berbatasan langsung dengan danau rawa pening, sedangkan secara data demografis (Desa Kesongo, 2014) dinyatakan sebagai desa dengan indeks kesejahteraan dengan kategori Keluarga Kepala (KK) Miskin dan Sedang yang cukup tinggi (Data monografi desa Kesongo tahun 2014 menunjukkan bahwa jumlah KK Miskin sebanyak $601 \mathrm{KK}$ dan KK dengan kesejahteraan sosial sedang sebanyak 1132 KK.). Sedangkan kondisi geografis desa Kesongo berbatasan langsung dengan rawa pening yang terkenal dengan fluktuasi populasi eceng gondok. Riady (2017) dalam Medan Bisnis Daily mencatat bahwa luas permukaan yang mencapai 2.700 hektar telah mengalami pendangkalan di mana hampir $70 \%$ permukaan danau tertutup oleh eceng gondok dan "upaya pembersihan dan pelatihan pemanfaatan eceng gondok belum mampu mengurangi tekanan populasi tumbuhan ini'. Namun dari kondisi demografis dan geografis tersebut, hanya penduduk yang belum bekerja/ tidak bekerja, buruh harian lepas, dan ibu rumah tangga yang berpotensi untuk mengolah eceng gondok untuk dijadikan komoditi desa.

Permasalahan kesejahteraan sosial masyarakat desa Kesongo dan permasalahan lingkungan yang besar di area Rawa Pening yakni pendangkalan sebagian besar permukaan Rawa Pening yang berbatasan langsung dengan desa Kesongo, menggerakkan kelompok masyarakat pegiat usaha UMKM Bengok Craft untuk memanfaatkan eceng gondok sebagai komoditi desa untuk mengurangi polusi eceng gondok dan juga untuk memberdayakan dan membantu perekonomian penduduk yang belum bekerja serta ibu rumah tangga. Unit usaha ini memproduksi puluhan kerajinan dari eceng gondok yang bermacam-macam mulai dari tas eceng gondok, buku, hingga sandal serta aksesoris lainnya. Banyaknya produksi kerajinan ini kemudian diproses lebih lanjut oleh UMKM Bengok Craft seperti proses finishing dan juga didistribusikan di pasar. Dalam distribusi produk, Bengok Craft menggunakan berbagai media baik luring maupun daring. Untuk media luring, Bengok Craft menggunakan strategi konsinyasi yakni menitipkan barang atau produk ke outlet atau toko untuk dibantu-jualkan, dengan ketentuan pihak toko yang dititipi produk tersebut mendapat keuntungan dari selisih harga barang atau produk yang terjual (Octa, 2018). Metode konsinyasi memiliki kelemahan yakni tidak mampu menjangkau khalayak global maupun internasional. Dalam rangka menjaring dan menarik minat pembeli global, Bengok Craft menambah strategi distribusi daring dengan memanfaatkan media sosial seperti tanpa bayar seperti Instagram dan juga menggunakan website.

Berdasarkan observasi dan wawancara yang dilakukan tim pengabdi, pegiat UMKM Bengok Craft memiliki banyak kendala dalam membuat konten kreatif dalam media distribusi terutama dari segi formulasi konten. Mereka menyatakan bahwa promosi dengan menggunakan gambar produk saja belum cukup menarik sehingga masih harus diperkuat dengan deskripsi teks yang menarik. Ditambah lagi, jika membidik pasar global maka konten berbahasa Inggris menjadi syarat mutlak. Mereka menyadari jika konten berbahasa Inggris masih harus ditingkatkan terutama terkait konsep isi/konten dan struktur bahasa sehingga lebih menarik dan persuasif. 
Dalam operasionalnya, terutama dalam hal periklanan, UMKM Bengok Craft masih belum melihat peluang pemanfaatan konten kreatif berbasis stori untuk menggaet lebih banyak konsumen baik konsumen lokal maupun internasional. Peluang untuk memaksimalkan penggunaan konten kreatif berbasis stori untuk media promosi, dapat digunakan untuk lebih memperkenalkan kekuatan produk kerajinan lokal yang memanfaatkan bahan yang merupakan sumber polusi air di Rawa Pening menjadi komoditi desa yang bernilai jual tinggi dan juga memiliki makna lebih di mata konsumen dengan memunculkan cerita di balik produkproduk eceng gondok.

Melihat permasalahan tersebut di atas, kami tim pengabdi ingin memberikan solusi pada pegiat UMKM Bengok Craft dalam hal penulisan konten kreatif pada media pemasaran daring berbasis stori berbahasa untuk mengoptimalkan potensi distribusi produk kerajinan dari eceng gondok yang dihasilkan masyarakat Desa Kesongo.

\section{Kajian Pendahuluan}

Terkait dengan penelitian penulisan konten kreatif untuk iklan produk, konten kreatif berbasis stori belum banyak dilakukan di Indonesia. Media iklan dengan strategi lebih banyak berfokus pada gambar visual sedangkan untuk konten iklan didasarkan pada humor.

Dianti dan Herawati (2013) melakukan kajian strategi iklan dengan pendekatan bernuansa lucu yakni parodi dalam iklan Axis. Konten dalam iklan berisi kritikan dan ejekan verbal terhadap kebiasaan masyarakat untuk menciptakan kesan paradoks. Selain itu, strategi visual dibuat berlebih-lebihan seperti tiruan sosok jin untuk menciptakan kesan lucu tapi paradoks.

Selain Dianto dan Herawati (2013), kajian strategi iklan kreatif dengan nuansa humor dilakukan oleh Adi (2016) dan
Wirasari \& Ferdiana (2018) meneliti strategi iklan melalui taktik visual dan penggunaan humor yang digunakan oleh perusahaan air minum kemasan "Aqua" dan e-commerce "Bukalapak". Dua peneliti tersebut menyatakan jika humor mampu "mempersuasi, menarik perhatian, mengingatkan dan meningkatkan penjualan". Humor-humor tersebut divisualisasikan dengan karakter aktor iklan misalnya aktor iklan yang sedang memegang bulu dada miliknya. Strategi humor dilekatkan bukan pada konten stori namun pada visualisasi tokoh atau aktor iklan.

Dari sampel kajian terdahulu diketahui bahwa strategi visual iklan sangat dapat menarik perhatian konsumen. Akan tetapi, pesan iklan memiliki peran yang penting. Kreativitas pesan iklan yang disampaikan secara humoris banyak dipakai oleh perusahaan untuk memasarkan produknya tidak terkecuali Aqua dan juga ECommerce, Bukalapak. Strategi iklan kreatif untuk produk komersial berbasis stori belum dikaji lebih lanjut dan belum ada tim pengabdi yang melakukan kegiatan penulis an iklan berbasis stori terutama terkait dengan lingkungan dan pemberdayaan masyarakat.

\section{Pemasaran Dan Iklan}

Iklan merupakan kegiatan dari tahapan pemasaran dilakukan dalam rangka mempromosikan produk agar dikenal masyarakat luas. Dikarenakan tujuan dari pemasaran adalah untuk memperkenalkan produk dan membuat produk tersebut diterima di masyarakat, maka aktivitas pemasaran berkaitan erat dengan identifikasi kebutuhan dan pemenuhan kebutuhan masyarakat. Oleh karena itu, Kotler (2002) mengartikan pemasaran sebagai "pemenuhan kebutuhan yang menguntungkan". Kotler menjelaskan bahwa cakupan pemasaran sendiri meliputi sepuluh entitas yakni barang, jasa, pengalaman, acara, orang, tempat, property, organisasi, informasi, dan gagasan. 
Secara garis besar, Kotler (2002) membagi definisi konsep pemasaran menjadi dua yakni konsep pemasaran sosial dan manajerial. Konsep pemasaran secara sosial diartikan sebagai proses sosial yang dilakukan seseorang ataupun kelompok dalam rangka mendapatkan apa yang mereka butuhkan dan mereka inginkan melalui penciptaan, penawaran, dan penukaran nilai produk dan jasa. Sedangkan konsep pemasaran manajerial diasosiasikan dengan aktivitas penjualan produk dan tujuan dari pemasaran adalah menciptakan penjualan. Lebih rinci lagi, Kotler menjelaskan bahwa konsep pemasaran manajerial adalah proses dari merencanakan dan melaksanakan konsepsi, strategi harga, promosi, dan distribusi gagasan, barang, dan jasa untuk menciptakan aktivitas saling tukar-menukar yang memuaskan seseorang (consumer) dan perusahaan/organisasi pemilik produk.

Untuk menciptakan penjualan, digunakanlah iklan sebagai salah satu aktivitas pemasaran. Kotler dan Amstrong dalam Rahmadawita, dkk (2014) mendefinisikan iklan sebagai "bentuk penyajian non-personal dan promosi ide, barang,atau jasa" di mana orang yang melakukan aktivitas periklanan membayar pada pemilik media iklan. Media iklan sendiri terbagi menjadi dua yakni cetak dan elektronik. Media cetak adalah segala bentuk media iklan yang dicetak pada kertas dengan ukuran tertentu, sedangkan media elektronik adalah iklan yang dimuat pada media berbasis elektronik. Saat ini media berkembang dengan adanya perkembangan internet yang disebut media digital.

Tujuan dari iklan sendiri menurut Kotler dan Amstrong dalam Rahmadawita, dkk (2014) diantaranya untuk memberi informasi, membujuk, dan mengingatkan. Memberi informasi meliputi aktivitas menginformasikan pasar perihal produk atau jasa, memperbaiki impresi yang salah, membangun atau membentuk citra, dan menghilangkan atau mengurangi keraguraguan konsumen. Membujuk meliputi aktivitas menciptakan pilihan konsumen terhadap produk atau brand, mengubah persepsi konsumen terhadap produk, membujuk konsumen untuk membeli produk, dan mendorong konsumen beralih ke pilihan produk atau brand tertentu. Terakhir, mengingatkan meliputi aktivitas membentuk persepsi agar produk selalu diingat oleh konsumen.

\section{Copywriting: Penulisan Iklan Kreatif}

Copywriting merupakan teknik atau seni penulisan iklan yang bertujuan untuk mendapatkan respon dari masyarakat maupun konsumen sasaran. Albrighton dalam Satria dan Agustine (2019) mengartikan copywriting sebagai bentuk pengoptimalan pemakaian Bahasa dalam rangka "promosi" serta "membujuk" konsumen atau audien sasaran.

Copywriting yang kreatif dapat membantu untuk memperoleh tanggapan positif dan lebih baik dari konsumen atau audiens sasaran. Oleh karena itu, seorang penulis iklan atau copywriter harus memiliki kreativitas dalam penulisan iklan. Kreativitas, menurut Warner dalam Satria dan Agustine (2019) dapat menghasilkan "keunggulan yang kompetitif'. Sebuah produk dijual dan berkompetisi di pasar sehingga kreativitas dalam konten periklanan menjadi hal yang sangat penting guna mendapatkan tujuan iklan yakni membujuk atau persuasi audiens atau atau konsumen sasaran.

\section{Langkah Pelaksanaan}

Dalam melaksanakan program pengabdian ini, tim pengabdi melakukan langkah kegiatan pengabdian yang meliputi persiapan, pelaksanaan pelatihan penulisan konten kreatif, dan evaluasi. 
1. Tahap persiapan meliputi kegiatan meliputi aktivitas rekrutmen peserta pelatihan dengan menggunakan media poster (lihat gambar 1 dan 2), persiapan tools dan materi pendampingan penulisan konten kreatif.

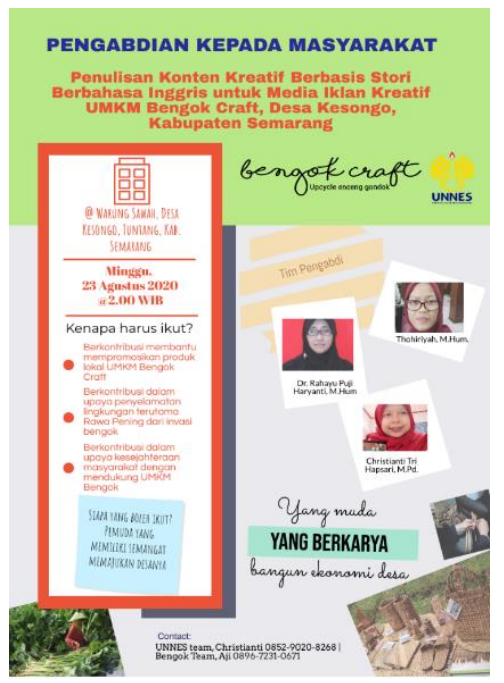

Gambar 1. Poster rekrutmen peserta penulisan konten kreatif untuk UMKM Bengok Craft Batch 1

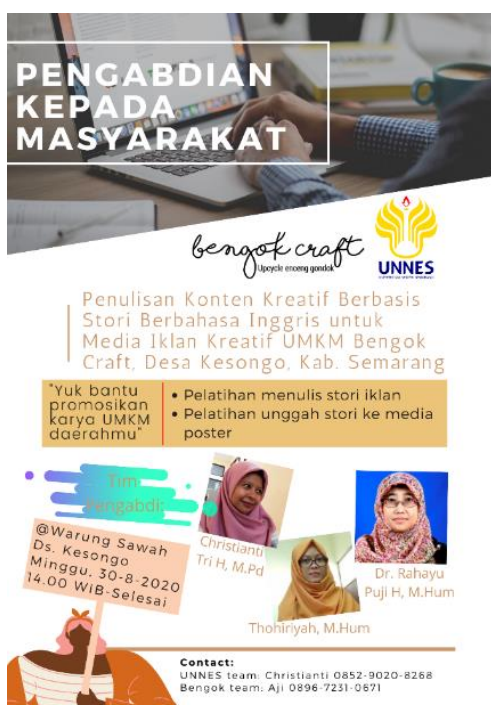

Gambar 2. Poster rekrutmen peserta penulisan konten kreatif untuk UMKM Bengok Craft Batch 2

2. Tahap pelaksanaan terdiri dari atas fasilitasi pelatihan penulisan konten iklan berbasis stori. Berikut adalah tahapan pelaksanaan kegiatan: a. Koordinasi internal dengan tim pengabdi (dosen Jurusan Bahasa dan Sastra Inggris, Fakultas Bahasa dan Seni, UNNES, dan tim peserta dari UMKM Bengok Craft di Desa Kesongo)

b. Pemberian materi pelatihan bersifat teoritis dengan metode ceramah dan diskusi

c. Praktik penulisan konten kreatif untuk iklan produk kerajinan eceng gondok UKMK Bengok Craft.

d. Pemberian umpan balik terhadap hasil praktik penulisan yang dihasilkan oleh peserta

3. Terakhir yakni tahap evaluasi. Tahapan ini dilakukan untuk mengkaji sejauh mana pelatihan memberikan dampak atau kontribusi bagi peserta latih dan mencatat kekurangan program untuk dijadikan saran atau rujukan bagi pengembangan kegiatan serupa di kemudian hari.

\section{Metode Penulisan Konten Iklan Kreatif}

Metode yang digunakan dalam penulisan konten iklan kreatif untuk memasarkan produk kerajinan eceng gondok yakni menggunakan metode copywriting berbasis stori. Leggett (1993: 188) menyatakan bahwa komponen sebuah stori setidaknya memiliki satu tokoh atau karakter. Plot disebut juga dengan storyline di mana plot merupakan komponen utama dalam sebuah stori. Plot diartikan sebagai rangkaian episode yang saling terkait di mana satu peristiwa berkembang atas peristiwa lainnya. Lebih lanjut Legget menjelaskan bahwa struktur plot terdiri dari pendahuluan (introduction), permasalahan yang dihadapi tokoh/klimaks permasalahan, dan resolusi. Berikut adalah ilustrasi struktur stori. 


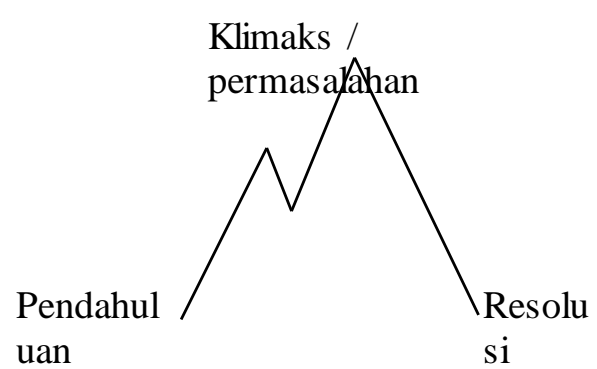

Gambar 3. Struktur stori

Dalam pelaksanaan penulisan konten iklan berbasis stori, peserta yang terlibat diberi pemahaman untuk menyusun storyline dengan baik yakni dengan melakukan identifikasi struktur stori, penentuan tema atau gagasan utama dalam sebuah stori yang akan disampaikan pada audiens, penggambaran setting, serta pembentukan tokoh stori.

\section{Hasil Dan Diskusi}

Kegiatan pelatihan penulisan konten kreatif berbasis stori untuk media iklan produk kerajinan Bengok Craft, Kecamatan Tuntang, Kabupaten Semarang, dilaksanakan dalam tiga tahapan besar kegiatan. Tahapan pertama adalah kegiatan pendahuluan yang terdiri dari brainstorming, pre-test, pengenalan struktur konten iklan kreatif, dan identifikasi struktur stori. Tahapan selanjutnya adalah pendampingan penulisan mulai dari eksplorasi struktur stori, eksplorasi storyline, dan meramu resolusi stori. Pada tahapan ini, peserta pelatihan akan dibimbing untuk mengembangkan stori sebagai bahan iklan produk. Tahapan terakhir adalah evaluasi untuk menganalisis hasil penulisan stori peserta pelatihan. Tiga tahapan utama tersebut dilakukan dalam kurun waktu 5 pertemuan yang dibagi menjadi pertemuan 2 kali pertemuan luring dan 3 kali pertemuan daring karena masih adanya pandemi covid-19. Peserta pelatihan juga dibatasi, dengan hanya menerima 10 orang peserta untuk pelaksanaan pertemuan luring. Tempat pelaksanaan pertemuan luring juga sudah melalui proses pertimbangan matang dengan mengutamakan, protokol kesehatan seperti penggunaan masker, hand sanitizer, dan akses untuk cuci tangan. Selain itu, pelatihan luring juga menerapkan physical distancing dan menggunakan tempat pelatihan yang memungkinkan adanya sirkulasi udara yang baik. Dua pertemuan luring digunakan untuk kegiatan pendahuluan dan kegiatan pengembangan stori serta evaluasi. Sedangkan tiga pertemuan daring digunakan untuk proses pendampingan penulisan mulai dari eksplorasi struktur stori, eksplorasi storyline, dan meramu resolusi stori.

\section{Kegiatan Pendahuluan}

Kegiatan pendahuluan dilakukan pada pertemuan pertama pelatihan secara luring di Warung Sawah, Desa Kesongo, Kecamatan Tuntang, Kabupaten Semarang, pada hari Minggu, 23 Agustus 2020, pukul 14.00. Pada tahapan ini, tim pengabdi melakukan beberapa tahapan kegiatan seperti brainstorming, pre-test, pengenalan struktur konten iklan kreatif, dan identifikasi struktur stori. Kegiatan pendahuluan ini diadakan dengan tujuan mengetahui kemampuan awal peserta pelatihan yang nantinya dapat digunakan sebagai dasar memberikan materi terkait konten iklan kreatif, stori, dan konten iklan kreatif berbasis stori.

\section{a. Brainstorming}

Dalam kegiatan ini, tim pengabdi mengajak peserta pelatihan untuk mengenal bagaimana sebuah iklan itu dapat dikategorikan sebagai iklan kreatif dan menarik. Kegiatan brainstorming ini dilakukan dengan metode tanya jawab, diskusi, dan simulasi. Tim pengabdi melontarkan beberapa pertanyaan terkait iklan untuk mengumpulkan ide-ide segar dari peserta tentang dasar-dasar iklan dan penyampaian iklan yang menarik dan efektif. Proses tanya jawab dan diskusi dilanjutkan 
dengan simulasi, mengajak peserta untuk trial menggunakan sosial media untuk mempromosikan sebuah produk di depan kelas, dilanjutkan pemberian feedback oleh tim pengabdi dan peserta lainnya. Pada tahapan ini, peserta cukup mengetahui dasar seperti apa iklan kreatif itu dan bagaimana iklan tersebut dapat menarik perhatian konsumen atau penonton. Namun, tantangannya adalah peserta pelatihan masih malu dan ragu untuk menyampaikan pemahaman dan pendapatnya secara gamblang. Tim pengabdi kemudian mendorong peserta pelatihan lebih aktif dalam kegiatan dengan terus memotivasi mereka untuk lebih lepas dalam mengungkapkan sesuatu dan berani menyampaikan pengetahuan dan pendapat yang mereka punya. Kegiatan ini diakhiri dengan penekanan kembali seperti apa sebuah iklan kreatif yang mampu menarik banyak konsumen atau penonton.

\section{b. Pre-test}

Pada tahapan ini, tim pengabdi memberikan potongan-potongan iklan produk berbahasa Indonesia kepada peserta untuk disusun menjadi sebuah kesatuan iklan yang baik dan menarik. Dalam kegiatan ini, tim pengabdi membagi peserta menjadi 5 kelompok, yang masing-masing kelompok berjumlah 2 orang. Di dalam kelompok, peserta harus menyusun potongan-potongan gambar dan narasi iklan yang diberikan oleh tim pengabdi menjadi sebuah iklan yang bagus dalam waktu 5 menit. Kegiatan ini ditujukan untuk mengukur pemahaman dan kemampuan dasar peserta terkait konten iklan kreatif berbasis stori. Pada akhir kegiatan, peserta di dalam kelompoknya mengutarakan hasil iklan yang telah disusun kemudian tim pengabdi akan memberikan feedback untuk meluruskan jika ada pemahaman atau jawaban yang kurang tepat. Kegiatan pre-test ini kemudian dilanjutkan dengan pemberian materi oleh tim pengabdi terkait materi bagaimana konsep dasar menulis konten kreatif untuk website/ sosmed dan video, apa itu kontek iklan kreatif berbasis stori dan kebermanfaatannya bagi promosi produk, bagaimana struktur iklan dengan konten kreatif berbasis stori, dan bagaimana struktur stori yang harus dibangun dalam sebuah konten iklan kreatif berbasis stori.

\section{c. Pengenalan Struktur Konten Iklan Kreatif Be rbasis Stori}

Tim pengabdi mengawali kegiatan dengan memberikan materi terkait struktur konten iklan kreatif berbasis stori. Setelah materi disampaikan, peserta kembali bekerja di dalam kelompok untuk menyusun konten iklan kreatif berbasis stori yang masih acak. Masih dengan kelompok yang sama, pada tahapan ini peserta harus mampu menyusun konten iklan kreatif berbasis stori dalam bahasa Inggris. Dalam kegiatan ini, peserta pelatihan tidak diperkenankan untuk menggunakan aplikasi penerjemah. Berbeda dengan hasil yang muncul ketika menyusun konten iklan kreatif berbasis stori berbahasa Indonesia dalam tahapan pre-test, di sini peserta mengalami kesulitan untuk menyusun kembali iklan sesuai dengan struktur konten iklan kreatif berbasis stori yang telah disampaikan oleh tim pengabdi. Muncul beberapa ketidaksesuaian seperti, tidak tepatnya penempatan tagline dan juga penempatan narasi. Setelah dipelajari lebih jauh, kendala ini muncul karena peserta pelatihan terkendala dalam memahami bahasa iklan yang digunakan karena masih berbahasa Inggris. Selain itu, beberapa peserta masih mengalami kesulitan untuk memahami perbedaan tagline, slogan, headline, dan subheadline. Berdasar hasil tersebut, kegiatan tim pengabdi difokuskan untuk memperkuat pemahaman terkait struktur konten iklan kreatif berbasis stori.

\section{d. Identifikasi Struktur Stori}


Kegiatan pelatihan dilanjutkan dengan pengenalan struktur stori yaitu pendahuluan, klimaks, dan resolusi. Kegiatan ini dilakukan seperti kegiatan lain, yang diawali dengan dengan pemberian materi dengan metode lecturing dan tanya jawab. Seperti sebelumnya, dalam proses kegiatan pengenalan struktur iklan kreatif berbasis stori, dalam tahapan ini, peserta juga diberikan latihan untuk mengidentifikas i struktur stori dalam contoh-contoh iklan yang diberikan oleh tim pengabdi, baik yang berbahasa Indonesia maupun yang berbahasa Inggris. Yang menarik dari proses ini adalah peserta sudah mampu membedakan struktur stori secara umum, yaitu pendahuluan, klimaks, dan resolusi. Namun jika struktur ini masuk ke dalam konsep iklan, peserta masih mengalami kesulitan untuk mengidentifikasikannya. Fokus peserta ketika melakukan identifikasi stori adalah dengan mengurutkan strukturnya. Hal ini mempengaruhi performa peserta ketika mengidentifikasi struktur stori, mereka mengalami kebingungan ketika menempatkan struktur pendahuluan, klimaks, dan resolusi dengan benar. Hal tersebut juga membuat peserta kurang memperhatikan adanya struktur lain yang berbarengan muncul dengan struktur stori dalam iklan, seperti tagline, slogan, logo, heading, dan subheading.

Kegiatan pendahuluan kemudian diakhiri dengan proses pembuatan draft awal penulisan konten iklan kreatif berbasis stori untuk UMKM Bengok Craft. Proses ini adalah sebagai latihan awal peserta dan juga sebagai pedoman awal tim pengabdi dalam mengembangkan materi pelatihan daring seperti eksplorasi pendahuluan, klimaks, dan resolusi melalui media WhatsApp yang digunakan untuk mengisi pertemuan kedua, ketiga, dan keempat. Pemilihan media pelatihan ini didasarkan kepada beragamnya latar belakang peserta pelatihan mulai dari yang melek sampai kurang cakap terhadap penggunakan teknologi. WhatsApp merupakan media yang mampu menjembatani perbedaan kecakapan teknologi tersebut karena sekarang hampir semua dapat menggunakan WhatsApp dan juga media sosial tersebut mampu menjadi media komunikasi untuk saling berbagi pengetahuan dan berdiskusi.

\section{Kegiatan Pendampingan Penulis an}

\section{a. Eksplorasi Struktur Stori}

Pada tahapan ini, tim pengabdi melakukan kegiatan dengan pendampingan secara daring. Kegiatan daring melalui WhatsApp dimulai dengan pemberian materi untuk dibaca dahulu oleh peserta pelatihan kemudian dilanjutkan dengan diskusi. Pada pertemuan kedua yang dilakukan secara daring tersebut, tim pengabdi memberikan materi yang meliputi apa itu stori atau narasi, tujuan, struktur, dan elemen-elemen yang harus ada agar menjadi suatu stori yang efektif. Pada kegiatan daring ini, tim pengabdi juga melakukan eksplorasi bagian awal struktur stori yaitu pendahuluan. Kegiatan eksplorasi dilakukan pada hari Kamis, 27 Agustus 2020, pukul 16.00. Kegiatan eksplorasi ini diawali dengan memberikan beberapa pertanyaan kepada peserta terkait apa itu iklan, seberapa sering melihat iklan, apa itu narasi, apa tujuannya, apa pentingnya narasi dalam sebuah iklan. Kegiatan ini dilakukan dengan metode tanya jawab dan diakhiri dengan penekanan kembali dan pelurusan pemahaman oleh tim pengabdi.

Masih menggunakan metode yang sama, yaitu diskusi, tim pengabdi memperkenalkan bagian pendahuluan pada stori, apa yang harus ada dalam sebuah pendahuluan dalam sebuah stori. Penjelasan juga meliputi apa itu hook dan thesis yang merupakan bagian dari pendahuluan. Proses diskusi kemudian diselingi dengan pemberian contoh video iklan kreatif berbasis stori yaitu iklan keju, Never Say No to Panda 
untuk dapat dibahas bersama, terutama bagian pendahuluannya. Diskusi terkait iklan panda tersebut berkisar tentang di bagian mana hooknya dan di bagian mana tesisnya. Tantangan yang dihadapi tim pengabdi adalah tidak meratanya keaktifan peserta pada saat pelatihan online dan durasi antara pemberian pertanyaan dan jawaban peserta memerlukan waktu tunggu yang lumayan panjang. Rangkaian kegiatan eksplorasi pendahuluan ini memakan waktu kurang lebih 5 jam, tidak termasuk jeda waktu sholat. Contoh video iklan panda yang diberikan oleh tim pengabdi mampu memberikan gambaran dasar terkait struktur pendahuluan sebuah stori, ini ditandai dengan betulnya semua jawaban peserta terkait identifikasi bagian-bagian pendahuluan pada iklan panda.

\section{b. Eksplorasi Story Line}

Kegiatan pendampingan ketiga dilakukan secara daring pada hari Jumat, 28 Agustus 2020 dengan agenda eksplorasi body/ klimaks dan juga identifikasi story line. Seperti sebelumnya, kegiatan diawali dengan pemberian materi kepada peserta di pagi hari dan kegiatan eksplorasi dilakukan di sore hari, pukul 17.00. Kegiatan dimulai dengan memberi jeda waktu bagi peserta untuk membaca dan mencerna materi. Kegiatan selanjutnya ada review materi pertemuan sebelumnya yaitu pendahuluan dan juga membahas karakter panda pada iklan keju dan apa yang membuat menarik serta mengaitkan dengan topik yang akan dibahas pada pertemuan tersebut. Iklan panda juga digunakan untuk membangun pemahaman peserta terkait identifikasi story line untuk menarik perhatian konsumen atau penonton. Kegiatan ini dilanjutkan dengan identifikasi body atau klimaks dari iklan Ramayana, iklan ini pernah digunakan tim pengabdi pada saat pelatihan luring pada pertemuan pertama. Untuk lebih memperdalam pemahaman peserta terkait materi pelatihan, tim pengabdi memberikan 3 contoh iklan dengan proses mengidentifikasi tema, setting, tokoh utama, pendahuluan, problems, klimaks, dan keunikan. Dari salah satu tanggapan peserta pelatihan terkait identifikasi story line, terlihat bahwa peserta cukup handal dalam melakukan identifikasi, ini tercermin dari jawaban peserta yang sudah sesuai dengan apa yang seharusnya. Kegiatan akhir diwarnai dengan penekan kembali pentingnya pengembangan storyline dalam sebuah stori untuk menciptakan stori yang kuat dan menarik. Selain itu juga, penting juga untuk menciptakan keunikan dalam sebuah cerita di iklan untuk dapat meninggalkan kesan yang membekas ke konsumen atau penonton. Seperti kegiatan sebelumnya, penugasan daring lanjutan adalah mengkonsep storyline dan mengembangkan body/ klimaks. Tugas tersebut dapat peserta pelatihan kumpulan pada link google docs yang sudah disediakan oleh tim pengabdi.

\section{c. Meramu Resolusi Stori}

Pertemuan terakhir secara daring adalah pertemuan keempat yang diadakan pada hari Sabtu, 29 Agustus 2020 dengan agenda meramu resolusi. Kegiatan diawali dengan pemberian materi untuk dibaca dan dicerna terlebih dahulu oleh peserta pelatihan beberapa jam sebelum kegiatan pendampingan dimulai. Kegiatan inti dimulai pukul 16.30, yang diawali dengan pembahasan langsung terkait resolusi dan identifikasi bagian resolusi pada tiga contoh video iklan yang pernah dipakai pada kegiatan sebelumnya, yaitu kegiatan eksplorasi body/ klimaks stori. Iklan yang dipakai adalah iklan Adidas, Mercedes, dan gubernur. Kegiatan ini juga diperkuat dengan pemberian teori terkait apa saja yang harus ditulis dalam sebuah resolusi narasi. Metode diskusi masih digunakan pada proses pendampingan online ini. Diskusi membahas terkait resolusi yang baik, mengidentifikas i 
tagline, slogan dan impresi konten iklan kreatif berbasis stori. Pada pertemuan terakhir secara daring ini, tantangan tim pengabdi untuk membuat peserta aktif dalam diskusi lebih besar. Ini terlihat dengan lebih lamanya waktu tunggu respon peserta terhadap pertanyaan dan pemberian materi oleh tim pengabdi, dan waktu tunggu tersebut lebih lama dari pertemuan daring sebelumnya. Sehingga walaupun materi yang diberikan lebih sedikit, waktu yang dibutuhkan oleh tim pengabdi dalam melakukan pendampingan hampir sama dengan kedua pertemuan daring sebelumnya. Beberapa peserta menjelaskan bahwa mereka mempunyai tugas-tugas lain yang harus segera diselesai sehingga kurang dapat fokus mengikuti pendampingan secara online. Seperti pertemuan daring sebelumnya, peserta pelatihan diberi tugas untuk membuat resolusi sebagai bagian dari rangkaian lanjutan tugas sebelumnya.

\section{d. Pengembangan Stori}

Pada pertemuan ke-lima yang dilakukan secara luring, pada hari Minggu, 30 Agustus 2020, pukul 14.00, tim pengabdi melakukan kegiatan akhir yaitu pendampingan pengembangan stori. Berbeda dari pertemuan sebelumnya, pertemuan kali ini difokuskan dengan metode murni workshop atau praktek langsung pengembangan stori mulai dari pembuatan storyline, pendahuluan, klimaks, dan resolusi. Fokus tim pengabdi tidak hanya pada pengembangan stori tapi juga storyline ini ditujukan agar peserta mempunyai dasar yang baik dalam pengembangan stori, terutama dalam mengembangan stori yang kuat dan menonjolkan keunikan sebuah stori. Dalam proses ini tim pengabdi memberikan feedback langsung terhadap storyline yang dibuat oleh peserta sehingga diharapkan stori line yang dibuat mampu mencerminkan sebuah draft awal stori yang kuat dan memiliki keunikan yang signifikan. Metode yang dilakukan tim pengabdi pada proses ini adalah dengan berkeliling dari satu grup ke grup yang lain untuk membantu peserta brainstorming ide yang dapat dituangkan dalam storyline dan pengembangan stori secara utuh. Dalam proses ini, peserta menghabiskan waktu lebih banyak dari perkiraan tim pengabdi. Peserta mengalami kesulitan untuk menuangkan ide yang akan dituangkan dalam storyline dan juga dan juga untuk dikembangkan dalam pendahuluan, klimaks, dan resolusi untuk konten iklan berstori milik mereka. Karena waktu banyak tersita pada saat brainstorming ide dan pengembangan story line, terutama dalam menemukan keunikan, ketika peserta mengembangkan stori mereka, alur stori yang dihasilkan menjadi kurang terlihat utuh. Ini terlihat dengan hasil penulisan stori peserta yang didalamnya ada pendahuluan, klimaks, dan resolusi kurang menunjukkan keruntutan kejadian.

\section{Analis is Hasil Tulisan Peserta Pelatihan}

Analisis hasil tulisan peserta pelatihan meliputi analisis storyline dan analisis konten stori. Fokus penulisan stori peserta adalah sebagai bahan iklan kreatif berbasis stori untuk UMKM Bengok Craft. Ada tiga tulisan peserta pelatihan yang akan menjadi fokus analisis tim pengabdian. Yang pertama adalah tulisan dari peserta A yang menuliskan stori bertema milenial dan bersetting di sebuah rawa café dan rumah produksi Bengok Craft. Dari hasil tulisan peserta terutama dibagian storyline, peserta tidak secara gamblang menyebutkan tokoh dalam cerita, peserta hanya menuliskan anak milenial. Pada tahap ini peserta kurang dapat menuangkan gambaran tokoh utama dari stori yang dia buat. Ketika stori ini berkembang ke bagian pendahuluan, problems, klimaks, dan keunikan, peserta masih menyamarkan tokoh yang ada di dalam cerita dengan menyebut $\mathrm{Si} \mathrm{A}, \mathrm{Si} \mathrm{B}, \mathrm{Si}$ C, dan Si D. Peserta juga melewatkan 
pengembangan keunikan stori yang merupakan nyawa dari sebuah iklan kreatif berbasis stori. Alur pendahuluan dari tulisan peserta A ini sudah cukup jelas dengan menghadirkan pengenalan tokoh, setting, dan apa yang dilakukan, namun ketika beranjak pada peralihan problem menjadi klimaks, ada penurunan tension dalam stori tersebut. Problem dimulai adanya perdebatan antara Si A dan Si B karena salah satu dari mereka tidak mau diajak ke Bengok Craft. Namun klimaksnya adalah tokoh lain muncul, yaitu Si D membawa salah satu produk Bengok Craft, namun tokoh yang tidak mau diajak ke Bengok Craft masih tidak bergeming atau tertarik. Stori ini menunjukkan bahwa problem lebih mengarah ke klimaks dan klimaks lebih terlihat hampir seperti resolusi. Stori juga kurang runtut pada transisi antara pendahuluan menuju problem, di mana awalnya masih santai-santai di sawah, dan semua tokoh ada di tempat tersebut yaitu $\mathrm{Si}$ A, Si B, Si C, dan Si D, tetapi tiba-tiba mengapa $\mathrm{Si}$ A tidak suka dengan eceng gondok dan berdebat dengan tokoh lain. Peralihan setting dari sawah ke café sebagai solusi perdebatan memunculkan kejanggalan lain yaitu Si D ternyata membawa produk Bengok Craft yang akhirnya membuat tokoh lain tertarik, termasuk juga tokoh A. Ada kejadian lain yang seharusnya muncul sebagai pengantar kejadian-kejadian tersebut, bagaimana $\mathrm{Si} \mathrm{D}$ bisa membawa produk Bengok Craft dan apa yang akhirnya membuat $\mathrm{Si} \mathrm{A}$ berubah pikiran, proses ini seharusnya dijelaskan lebih mendalam. Yang menjadi kekuatan tulisan ini adalah penggunaan pilihan kata yang bisa digunakan untuk mendramatisir cerita, seperti penggunaan kata senja. Dan juga tema yang diangkat adalah milenial, di mana kaum ini yang sering mengalami proses dinamika belajar menghargai produk ramah lingkungan berbasis kearifan lokal.

Tulisan peserta kedua, atau peserta B adalah stori dengan tema hari Ibu dengan setting di lapangan, sekolah, rumah dan masjid. Tokoh yang muncul adalah Udin, Ibu, Budi, Jaka, dan Ikha. Dari penentuan tema, setting, dan tokoh, terlihat bahwa peserta B sudah cukup lihai. Sedangkan pada jalannya cerita dari pendahuluan, peserta B juga sudah mampu mengenalkan setting waktu, tempat, tokoh dan kegiatan yang dilakukan. Penulisan problem dan klimaks juga sudah runtut dengan adanya penjabaran masalah yaitu bingung mencari hadiah untuk hari Ibu tapi belum ketemu karena yang ditemukan yang mahal-mahal, tidak sesuai dengan uang tabungannya. Klimaks stori berkembang dengan kejadian Ibu Udin putus sandalnya di masjid, kejadian ini sering berulang, sehingga membuat Udin berusaha mencari hadiah sandal yang tidak gampang putus. Yang sedikit kurang sesuai dengan konsep sandal dalam cerita ini adalah cepat hilang, karena ketika sandal di masjid cepat hilang itu tidak memandang bulu sandal merk apa, biasanya akan tetap sering hilang di masjid. Resolusi stori ini juga bagian dari kekuatan stori ini dengan memperkenalkan produk sandal dari Bengok Craft yang dibeli Udin di media sosial, sandal yang dipercaya Udin talinya tidak gampang putus, pada tahap ini, penulis dapat menambahkan narasi, mengapa Udin bisa percaya diri kalau sandal Bengok Craft tidak gampang putus untuk memperkuat kekuatan produk yang dipromosikan. Dari segi keunikan, stori yang ditampilkan cukup unik karena mengangkat produk Bengok Craft dari segi ekonomis dan dari segi ketahanan, mungkin bisa ditambahkan dengan keunikan dari bahan dasar sandal Bengok Craft tersebut yaitu Bengok.

Analisis selanjutnya adalah tulisan dari peserta C. Peserta ini mengangkat tema ruang. Tema yang sudah unik sejak dari awal pengembangan story line. Setting stori adalah rawa dan tokohnya ada sepasang ikan. Tokoh dari cerita ini memperkuat keunikan dari stori ini. Dari perspektif penulis, Bengok Craft 
adalah tokoh yang membantu sepasang ikan untuk lebih punya ruang bersih dan bebas di rawa karena populasi bengok berkurang. Penulis menceritakan bahwa karena adanya lonjakan populasi bengok di rawa, sepasang ikan sulit untuk bertemu, namun karena ada tokoh lain membantu mengurangi bengok, ikan tersebut akhirnya bisa bertemu dengan leluasa. Kekuatan tulisan ini terlihat dengan pilihan setting dan tokoh peserta yaitu rawa dan ikan. Namun dalam cerita tersebut, penulis belum menghubungkan cerita dengan produksi UMKM Bengok Craft. Dan dari ketiga cerita di atas, masih belum ada tagline yang dapat digunakan sebagai ciri khas, kekuatan iklan kreatif.

\section{Diskusi}

Proses pelatihan konten iklan kreatif berbasis narasi ini mampu memperkenalkan dasar teori pengembangan stori untuk tujuan iklan, namun pelatihan ini masih menyisakan kendala dalam proses pengembangan penulisan stori. Praktek menulis memang seharusnya dilakukan berkali-kali dalam jangka waktu yang panjang, terutama jika bahasa yang digunakan dalam penulisan adalah bahasa yang masih kurang dikuasai yaitu Bahasa Inggris. Kendala bahasa dapat menghambat penulis untuk menuangkan ide ke dalam kalimat-kalimat dengan baik dan benar, selain itu juga waktu yang diperlukan untuk menulis menjadi lebih lama karena harus menerjemahkan ide dari Bahasa Indonesia ke Bahasa Inggris (Nuzhatun, 2016). Menurut Mustafa dan Efendi (2016), kurang maksimalnya hasil tulisan narasi disebabkan oleh sistem pengajaran di Indonesia yang masih berfokus pada tata bahasa dan teori. Fokus pembelajaran terutama untuk melatih kemampuan mengarang masih sering dikesampingkan. Dan karena fokus peningkatan kemampuan menulis itu membutuhkan proses bukan pada hasil saja, yang masih minim dilaksanakan di Indonesia, menyebabkan ada tendens $i$ seseorang enggan untuk menulis cerita melalui proses penciptaan cerita (Endraswara, 2005). Proses berlatih menulis narasi juga membuat enggan dikarenakan kesulitan penulisan berhubungan dengan sulitnya menentukan tema, menyusun kalimat, dan malu (Kurniawan, 2012). Hasil penelitian di atas sejalan dengan apa yang dihadapi tim pengabdi pada saat melakukan pelatihan pembuatan konten iklan kreatif berbasis stori, di mana peserta masih kesulitan untuk menuangkan ide, menentukan tema, dan menyusun kalimat menjadi kalimat yang runtut. Yang menarik adalah dengan pendekatan iklan komersial berbasis stori mampu membuat kemampuan menulis narasi berkembang menjadi lebih baik seperti penelitian yang dilakukan oleh Andini (2015). Yang menjadi catatan adalah proses menulis untuk sampai pada tahap mahir dan menghasilkan tulisan yang mumpuni memerlukan jam tayang penulisan yang tinggi dan banyak latihan. Karena sekali lagi kemampuan ini membutuhkan proses, tidak sekedar hasil saja. Diperlukan banyak input contoh-contoh iklan kreatif berbasis stori dan latihan penulisan iklan kreatif berbasis stori untuk dapat menghasilkan konten iklan berkualitas dan mampu menarik konsumen atau penonton.

Sedangkan kendala yang muncul ketika menggunakan WhatsApp adalah waktu tunggu respon peserta pelatihan yang lama dan keaktifan yang kurang merata, hal ini merupakan hasil yang berbeda dengan penelitian yang dilakukan sebelumnya oleh Ma'ruk, dkk (2019) dan Wijaya (2020). Mereka menyebutkan bahwa penggunaan WhatsApp bermanfaat dalam menunjang pembelajaran dan meningkatkan performa dalam proses pembelajaran. Walaupun terdapat kendala teknis seperti terbatasnya kuota internet dan kurang stabilnya jaringan internet, hal ini tidak mengurangi kebermanfaatan WhatsApp dalam pembelajaran. Namun yang menjadi catatan 
adalah, penggunaan WhatsApp tersebut dilakukan dalam setting sekolah formal di mana siswa ada kebutuhan mendasar untuk belajar dan berpartisipasi aktif dalam pembelajaran. Hal ini yang membedakan proses pengembangan kemampuan menulis yang dilakukan dalam konteks informal seperti pelatihan di luar kewajiban inti peserta. Terkadang komitmen untuk betulbetul ikut serta aktif dalam pelatihan yang menjadi tantangannya.

\section{Simpulan}

Berdasarkan kegiatan yang telah dilakukan, pengabdi menyimpulkan bahwa peserta pelatihan memiliki cukup semangat untuk mengembangkan kemampuan menulis konten kreatif berbasis stori yang selama ini masih terkendala kurangnya pendampingan dan latihan. Kendala seperti susahnya menuangkan ide dan merangkai kalimat menjadi sebuah stori yang utuh tidak menyurutkan niat peserta untuk menghasilkan karya kreatif yang dapat digunakan untuk promosi UMKM Bengok Craft. Kegiatan pelatihan ini menghasilkan draft awal stori yang dapat diolah sebagai konten iklan UMKM Bengok Craft. Kemampuan peserta dalam mengembangkan storyline dan stori sudah cukup bagus, hanya diperlukan penambahan durasi pendampingan untuk memperbaiki stori yang kurang runtut dan mempertajam keunikan serta mengurangi gap kendala bahasa. Pengabdian lanjutan dapat dilakukan dengan menambah durasi waktu pelatihan untuk memfokuskan bimbingan pada pengembangan stori yang sistematis dan runtut sampai dengan pendampingan pengolahan konten iklan kreatif berbasis stori menjadi bahan yang siap untuk di post di media sosial.

\section{Pernyataan}

Ucapan terima kasih kepada Fakultas Bahasa dan Seni, Universitas Negeri
Semarang atas dukungan yang diberikan pada tim pengabdi. Program pengabdian ini dilaksanakan atas biaya DIPA UNNES Tahun 2020.

\section{Referensi}

Adi, Enricho P. (2016). Pengaruh Kreativitas Iklan, Unsur Humor, dan Kualitas Pesan Iklan terhadap Efektivitas Iklan Televisi Aqua "Versi Ada Aqua. Jurnal Manajemen Bisnis Indonesia (JMBI), Vol 5, No 2 (2016) http://journal.student. uny.ac.id/ojs/in dex.php/jmbi/artic le/view/5019

Andini, N. H. (2015). Penggunaan Media Tayangan Iklan Komersial pada Pembelajaran Menulis Karangan Narasi. Skripsi S1: Universitas Pendidikan Indonesia.

Cholewa-Wójcik A., Kawecka A. (2015), The Influence of Effectiveness of Packaging Elements on the Consumers' Preferences with the Use of Marketing Eye-Tracking Technique, Modern Management Review, Vol. 20 (1), pp. 49-61

Desa Kesongo. (2014). Sejarah Desa Kesongo "Bermartabat". Retrieved August 10, 2020 from http://desakesongo.blogspot.com/

Dianti, Dyah E. \& Herawati, F.A. (2013). Implementasi Konsep Kreatif Pendekatan Parodi Dalam Iklan Televisi Axis. E-Journal Universitas Atma Jaya Yogyakarta, 2013. http://e journal.uajy.ac.id/4297/1/Jurnal.pdf Escalas, J. E. (2006). Self-referencing and persuasion: Narrative transportation versus analytical elaboration. Journal of Consumer Research, 33(4), 421-429.

Kotler, Philip. (2002). A Framework for Marketing Management. New Jersey: Prentice-Hall, Inc.

Kurniawan, K. (2012). Belajar dan Pembelajaran Bahasa dan Sastra 
Indonesia. Bandung: Bangkit Citra Persada.

Legget, John. (1993). Elements of Literature. Austin, Orlando, San Diego, Chicago, Dallas, Toronto: Holt, Rinehart and Winston, Inc.

Mustafa, Devy A. I., \& Efendi, A. (2016). Pengembangan Bahan Ajar Pembelajaran Menulis Cerita Berbasis Pendekatan Proses bagi Siswa SMP. LingTera, Vol. 3(1), 1-8.

Nuzhatun, L. (2016). An Analysis of Students' Problems in Writing Narrative Text: A Case Study at Second Grade Students of SMKN 1 Praya Tengah in Academic Year 2015/2016. Skripsi S1: Universitas Mataram.

Octa, Agus. (2018). $7 \quad$ Tips Sukses Konsinyasi, dalam Distribusi Produk Baru. Retrieved August 10, 2020 from

https://distribus ipemasaran.com/7tips-sukses-konsinyasi-dala mdistribusi-produk-baru/

Padgett, D., \& Allen, D. (1997). Communicating experiences: A narrative approach to creating service brand image. Journal of Advertising, 26(4), 49-62.

Rahmadawita, Tuti, dkk. (2014). Analisis Pengaruh Kreativitas Iklan, Daya Tarik Iklan dan Kualitas Pesan Iklan terhadap Brand Attitude pada Produk Blackberry Z10 di Kota Pekanbaru. Jurnal Online Mahasiswa Fakultas Ekonomi Universitas Riau, Vol 1, No 1 (2014).

Riady, S. (2017). Rawa Pening Menuju Destinasi Wisata Kelas Dunia. Retrieved August 10, 2020 from

http://www.medanbisnis daily.com/ne ws/read/2017/08/09/314150/rawapening-menuju- destinasi-wisatakelas-dunia/
Satria, Hardika W \& Agustine, Dewi K. (2019). Tinjauan Alur Kerja Copywriter Divisi Konten Suitmedia dalam Industri Kreatif Pemasaran Digital. Jurnal Sosial Humaniora Terapan, Volume 2 No.1, JuliDesember 2019. Taylor, R. E. (1999). A six-segment message strategy wheel. Journal of Advertising Research, 39(6), 7-17. West T. (2015), Brand Storytelling with Sequential Advertising on Facebook, http://www.stateofdigital.com/brands torytelling-sequential-advertisingfacebook/ (22.03.2018).

Wijaya, A. (2020). Students' Responses toward the Use of Whatsapp in Learning. Journal of Teaching \& Learning English in Multicultural Contexts, Volume 2(1), 46-55.

Wirasari, Ira \& Ferdiana, Tresna. (2018). Strategi Kreatif Tema Kepahlawanan dalam Iklan Media Sosial. Bukalapak. 